International Journal of Medical Arts 2020; 2 [1]: 253-259.

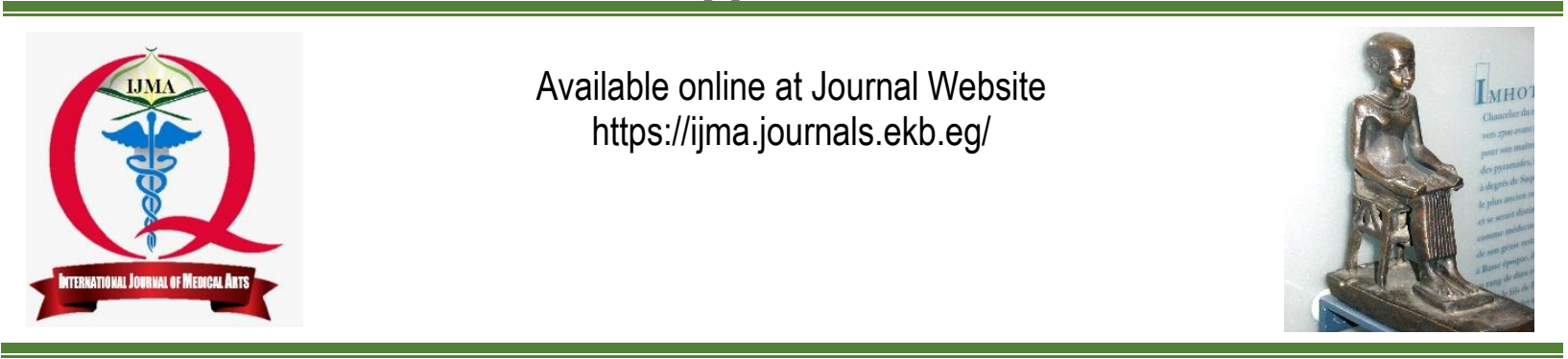

Original article

\title{
Prevalence of Noise Induced Hearing Loss among Employees at Wood Industry in Damietta Governorate
}

\author{
Waheed Hussein Elsaidy, Ayman Ahmed Mahmoud \\ Department of Community Medicine, Damietta Faculty of Medicine, Al-Azhar University, Egypt
}

Corresponding author: Waheed Hussein Elsaidy

Email: dr.wahid81@gmail.com

Received at: December 14, 2019; Revised at: January 7, 2020; Accepted at: January 26, 2020; Available online at: January 26, 2020

\section{ABSTRACT}

Background: Occupational noise-induced hearing loss $(\mathrm{ONIHL})$ is a major health issue with high prevalence globally and has major social, economic and psychological effects.

Aim of the work: Assessment of noise induced hearing loss $(\mathrm{NIHL})$ prevalence among employees at wood industry in Damietta governorate.

Patients and methods: The present cross-sectional study was carried out in New Damietta city, Damietta governorate, Egypt. Ten workplaces were selected through convenience sampling. From these ten workplaces, one hundred fifty (150) employees agreed to participate in the study. Pure-tone audiometry between 500 and $8000 \mathrm{~Hz}$ frequencies determined the hearing condition of the participants and noise readings were conducted at the selected workplaces.

Results: Among all study participants, the prevalence of noise induced hearing loss (NIHL) was 39\% of carpenters and $44.4 \%$ of sawyers with no statistically significant difference $(P=0.253)$ between both groups. Noise levels ranged from 73 to $91.5 \mathrm{dBA}$ in the various furniture factories and from 74.9 to $94.1 \mathrm{dBA}$ in the different saw mills.

Conclusion: Occupational noise induced hearing loss $(\mathrm{ONIHL})$ is highly prevalent in Damietta governorate among wood workers, which might be due to lack of knowledge, awareness about NIHL among employers, workers, and health care workers along with absence and or implementation of hearing conservation programs in the work places.

Keywords: Wood workers; Noise induced hearing loss; Occupational health; Safety; Damietta.

This is an open access article under the Creative Commons license [CC BY] [https://creativecommons.org/licenses/by/2.0/]

Please cite this article as Elsaidy WA, Mahmoud AA. Prevalence of Noise Induced Hearing Loss among Employees at Wood Industry in Damietta Governorate. IJMA 2020; 2[1]: 253-259. 


\section{INTRODUCTION}

Hearing loss due to exposure to noise in occupation defined as occupational noise induced hearing loss $(\mathrm{ONIHL})$, which is considered one of a major health issues and a pervasive global occupational health risks with significant social, economic, and psychological effects. These effects may be auditory only (impaired hearing, poor communication) or extend beyond auditory effect to disrupted well-being. ${ }^{[1]}$ Noise-induced hearing loss (NIHL) is considered one of the most common causes of sensorineural hearing loss. It occurs due to long exposure to noise without any protective devices. It is completely different from presbycusis which is age related sensory neural hearing loss. The pathology of hearing loss in NIHL started when high loud sound damage the stereocilia which is present on the top of hair cells in the inner ear; these intensities can cause cell death if excessive, and when the stereocilia are damaged, the hair cells lose the ability to send signals about the sound to the brain. The end result of these changes inside the inner ear may lead to permanent hearing loss (NIHL) [2].

According to World Health Organization (WHO), occupational noise induced hearing loss (ONIHL) represents $16 \%$ of the disabled hearing loss in adults, with estimates of the disease burden varying from $7 \%$ in developed countries to $21 \%$ in developing countries. The rate of disabled hearing loss above $40 \mathrm{~dB}$ from all causes increased all over the world over the past two decades from 120 million to 466 million people between 1995 to 2018[3].

Exposure to excessive noise initially results in a temporary or transient fall in hearing acuity, which is called temporary threshold shift (TTS), that drop in hearing acuity returns to normal within hours after the noise stops. But if the exposure to noise continues and prolonged may be led to a permanent loss of hearing which is called a permanent threshold shift (PTS) or with another definition noise induced hearing loss (NIHL). This PTS or NIHL typically appears on an audiogram (a graph shows the audible threshold for specific frequencies) as a dip or notch between 3 and $6 \mathrm{kHz}$ with a subsequent recovery at $8 \mathrm{kHz}[4]$. Numerous studies have declared that exposure to high noises greater than 85 decibels has the potential to cause hearing loss that may be temporary (TTS) or permanent (PTS). In addition, it was found out that occupational exposure to $85 \mathrm{~dB}$ or higher noise has been shown to cause not only auditory effects but also extra auditory effects. For example, exposure to noise in work place can reduce work efficiency and increase employee's liability for mistakes, and therefore may expose workers to risks and also affect production by increasing loss of working hours [5]. There are few studies concerning with $\mathrm{NIHL}$ in the timber industry in developing countries. For example, a study conducted in Nepal in 2015 found that the prevalence of NIHL among wood workers was high, and the study concluded that among 88 carpenters and 36 sawmills the prevalence of $\mathrm{NIHL}$ was $16 \%$, $27 \%$ respectively and the average noise exposure was $84.2 \mathrm{dBA}\left[{ }^{[6]}\right.$.

\section{AIM OF THE STUDY}

The study aimed to assess the noise levels and the prevalence of noise induced hearing loss $(\mathrm{NIHL})$ among employees at wood industry in Damietta governorate.

\section{PATIENTS AND METHODS}

Setting and population: The current work was designed as a descriptive cross-sectional study conducted in New Damietta city, Damietta, Egypt. This governorate in Egypt is very famous for its furniture industry. Ten workplaces (small-scale businesses) were selected through convenience sampling. All workplaces identified in the study were small businesses hiring between three and twenty employees. From all employees competent with the inclusion and exclusion criteria one hundred fifty (150 employees) agreed to participate in the study from these workplaces with $95.6 \%$ response rate.

Inclusion criteria: The study include woodworkers working in new Damietta city aged $\geq 18$ years and who have been in their current job for 1 year.

Exclusion criteria: Current pathology of the outer or middle ear, including otitis externa, impacted cerumen, perforated tympanic membrane, acute otitis media, and cholesteatoma. Previous exposure to occupational noise in a different job or a different place and/or Conductive hearing loss indicated by an air-bone gap $>20 \mathrm{dBHL}$ at two or more adjacent frequencies on pure-tone audiometry. 
Data collection: The employees involved in the study had completed an oral questionnaire in both Arabic and English language with the aid of the researchers (interview questionnaire). The questionnaire was designed to collect demographic data, occupational history, average working hours, use of personal protective devices (muffs, plugs or both), and previous occupational noise exposure. All employees' ears were examined by Otoscope (LM02T-Y Otoscope, Led Whit Light) before conducting the pure audiometry to exclude any other causes of hearing loss. Any employee was found to have any existing bilateral outer or middle ear disease was excluded from the study and referred to ENT specialist for more investigations, diagnosis and treatment.

Pure-tone audiometry was conducted in two stages; Air-conduction hearing thresholds were determined in each ear at the frequencies 500 , $1000,2000,3000,4000,6000$, and $8000 \mathrm{~Hz}$, followed by bone-conduction thresholds at 500 , 1000,2000 , and $4000 \mathrm{~Hz}$. The object of determining the bone conduction threshold shift test was to diagnose those with a conductive hearing loss (i.e. not caused by noise), which were then excluded from the study. An otometric MADSEN I tera II portable diagnostic audiometer (made in USA), meeting International Electrotechnical Commission (IEC) 645 standards, American National Standards Institute (ANSI) S3.6 and International Organization for Standardization (ISO)389 was used. All audiometric testing conducted at Damietta Health Insurance Hospital in a quietly prepared room. A RadioShack sound level meter ranged 50-150 dB (made in China) and was used for assessment of noise level in the selected work places (furniture factories and sawmills). ${ }^{[7]}$

In audiometry, presence of a notch between 3 and $6 \mathrm{kHz}$ and hearing threshold level $(\mathrm{HTL})>25$ $\mathrm{dB}$ at 3 and $6 \mathrm{kHz}$ was diagnosed as sensory neural hearing loss (SNHL) if found to be higher than the predicted of age. Those who met these requirements were further graded according to $\mathrm{NIHL}$ 's severity to mild (26-40 dB), moderate (41-60 $\mathrm{dB})$ and sever (61-80 dB) NIHL [8].

\section{Noise measurements}

Noise level readings were taken from all workplaces participating in the study using the aforementioned sound level meter from RadioShack. Three measurements of A-weighted equivalent continuous sound level $\left(L_{\text {Aeq }}\right)$ were collected every hour from a fixed point which located one meter away from a specific noise source recorded on three non-consecutive days to compensate random noise variations ; from these, the mean A-weighted equivalent continuous sound level in decibels $\left(L_{\text {Aeq }}\right)$ for a workplace was calculated.

Statistical analysis: SPSS version 25 was used for data analysis. Initially, the normality tests of Shapiro - Wilk were used to evaluate continuous variables distributions. Medians and interquartile ranges (IQRs) represent the central tendencies of nonquantitative data, while means and standard deviations (SDs) represent quantitative data. The prevalence of noise induced hearing loss $(\mathrm{NIHL})$ and hearing impairments $\mathrm{HI}$ was calculated for each group and compared using Chi-squared tests to detect any significant differences. For comparison of non-parametric continuous data between furniture and sawmills populations, MannWhitney $U$ tests have been used. In all cases, statistical significance established if $P$ value $<0.05$. In order to determine the factors influencing HTL at each frequency and the existence of $\mathrm{NIHL}$ and $\mathrm{HI}$, multiple linear and binary logistic regression analyzes were carried out on the combined population of woodworkers.

\section{RESULTS}

From ten different furniture factories and sawmills located in New Damietta city, one hundred and fifty wood workers (150) were participated in the current study; 105 worked as carpenters and 45 as sawyers. All participants were males (no females), because in the wood industry in Damietta, Egypt there are no female employees. Age of workers $(P=0.001)$ and duration in occupation $(P=0.023)$ were statistically significant between sawyers and carpenters. previous exposure to noise among sawyers was $33.3 \%$ which higher than that of carpenters (14.3\%) with significant difference $(P=0.032)$. [Table 1]

Overall the surveyed populations, the prevalence of noise induced hearing loss $(\mathrm{NIHL})$ was $39 \%(41 / 105)$ in carpenters and $44.4 \%(20 / 45)$ in sawyers with no statistically significant difference 
$(P=0.253)$ between the both groups. $H I$ was $8 \%$ $(9 / 105)$ among carpenters and $15.5 \%$ among sawyers respectively with also non-significant difference in prevalence of $\mathrm{HI}$ between the carpenters and sawyers $(P=0.134)$. [Table 2]

In the present study the average age among all wood workers diagnosed to have noise induced hearing loss (NIHL) was 34 years, compared to 26 years among non-NIHL participants with significant difference $(P<0.001)$ between the both groups. In addition, the average duration in occupation was higher (11years) in the participants was diagnosed to have NIHL than who was not diagnosed to have $\mathrm{NIHL}$ whereas the average was (6 year) with significant difference $(P<0.001)$ between the both groups. [Table 3]

Noise measurements using sound level meter were taken from five furniture factories and five saw mills. A-weighted equivalent continues sound in decibel (LAeq) values ranged from 73 to $91.5 \mathrm{dBA}$ at the furniture factories and 74.9 to $94.1 \mathrm{dBA}$ at sawmills. On the other hand, the average LAeq readings exceeded the permissible exposure limit (90 dBA) at five workplaces, three sawmills and tow furniture factories. [Table 4]

Multiple linear regression analyses were used; the independent variable was hearing threshold level (HTL) at a specific frequency ranged from 500 $\mathrm{Hz}$ to $8000 \mathrm{~Hz}$ while the independent variables was included age, occupancy time (duration in occupation), smoking status (non-smokers or exsmokers or current smokers), occupation (carpenter or sawyer) and previous exposure to loud noise (yes or no). duration in occupation was significantly associated with hearing threshold level (HTL) at $1000,2000,3000$, and $4000 \mathrm{~Hz}$, while age was significantly associated with $\mathrm{HTL}$ at 4,6 , and 8 kHz. [Table 5]

Table [1]: Descriptive characteristics of the participants in the study

\begin{tabular}{|l|l|c|c|c|}
\hline \multicolumn{2}{|c|}{ Characteristic } & Carpenter, $n=105$ & Sawyers, $n=45$ & P value* $^{*}$ \\
\hline Age (years) & Median; IQR & $25 ; 18-33$ & $33 ; 23-47$ & $0.001^{\prime \prime}$ \\
\hline Duration in occupation (years) & Median; IQR & $5 ; 2-12$ & $11 ; 4-18$ & $0.023^{\prime \prime}$ \\
\hline Work hours/Day (hours) & Median; IQR & $10 ; 8-12$ & $9 ; 8-11$ & $0.242^{\prime \prime}$ \\
\hline Work days/Week (days) & Median; IQR & $5 ; 5-6$ & $6 ; 5-6.5$ & $0.869^{\prime \prime}$ \\
\hline Previous exposure to noise & Yes & $15(14.3)$ & $15(33.3)$ & $0.032^{£}$ \\
\hline Use of protection devices & No & $90(85.7)$ & $30(66.7)$ & $0.979 €$ \\
& Yes & $3(2.9)$ & $4(8.9)$ & \\
\hline & No & $98(97.1)$ & $41(91.1)$ & $0.130^{€}$ \\
\hline
\end{tabular}

${ }^{*} P<0.050$ indicates statistical significance. "Mann-Whitney $U$ test.

IQR Interquartile range.

$€$ Chi-squared test.

Table (2): Comparison of noise induced hearing loss (NIHL) and hearing impairment $(\mathrm{HI})$ according to the level of severity between carpenters and sawyers

\begin{tabular}{|c|c|c|c|c|c|c|}
\hline \multirow[t]{2}{*}{ Type of hearing loss } & \multirow[t]{2}{*}{ Severity } & \multicolumn{2}{|c|}{$\begin{array}{c}\text { Carpenters } \\
(n=105)\end{array}$} & \multicolumn{2}{|c|}{$\begin{array}{c}\text { Sawyers } \\
(n=45)\end{array}$} & \multirow[t]{2}{*}{$P$ value } \\
\hline & & $\mathbf{N}$ & $\%$ & $\mathbf{N}$ & $\%$ & \\
\hline \multirow{4}{*}{$\mathrm{NIHL}^{\approx}$} & Mild & 15 & 14.3 & 8 & 17.7 & \multirow{4}{*}{0.253} \\
\hline & Moderate & 14 & 13.3 & 8 & 17.7 & \\
\hline & Severe & 12 & 6.7 & 4 & 8.9 & \\
\hline & Overall & 41 & 39 & 20 & 44.4 & \\
\hline \multirow{4}{*}{$\mathrm{HI} \dagger$} & Mild & 5 & 4.8 & 4 & 8.9 & \multirow{4}{*}{0.134} \\
\hline & moderate & 3 & 2.9 & 2 & 4.4 & \\
\hline & Sever & 1 & 0.9 & 1 & 2.2 & \\
\hline & Overall & 9 & 8 & 7 & 15.5 & \\
\hline
\end{tabular}


Table (3): Comparison between NIHL and non-classified NIHL in carpenters and sawyers according to age, work hours per day and duration in occupation

\begin{tabular}{|c|c|c|c|c|}
\hline \multicolumn{2}{|c|}{ Characteristic } & Non-classified NIHL & NIHL & $\begin{array}{c}\text { "Mann-Whitney U test } \\
\text { P value* }\end{array}$ \\
\hline Age (years) & Median; IQR & $26 ; 19-31$ & $34 ; 25-45$ & $\mathbf{0 . 0 0 1}^{*}$ \\
\hline Duration in occupation & Median; IQR & $6 ; 5-9$ & $11 ; 6-15$ & $0.001^{*}$ \\
\hline Work hours/day & Median; IQR & $10 ; 8-12$ & $\mathbf{9} ; 8-12$ & 0.212 \\
\hline
\end{tabular}

${ }^{*} \mathrm{P}<0.050$ indicates statistical significance. "Mann-Whitney U test.

Table (4): Noise levels measurements at selected furniture factories and saw mills

\begin{tabular}{|c|l|c|c|c|c|}
\hline \multirow{2}{*}{ Workplace Number } & \multirow{2}{*}{ Workplace type } & \multicolumn{3}{|c|}{ Noise level (dBA) } & \multirow{2}{*}{ Mean LAeq \pm SD (dBA) } \\
\hline & & LAeq 1 & LAeq 2 & LAeq 3 & $80.6 \pm 6.4$ \\
\hline $\mathbf{1}$ & Furniture factory & 85 & 73 & 83.9 & $84.8 \pm 1.5$ \\
\hline $\mathbf{2}$ & Furniture factory & 82.8 & 85.5 & 86 & $78.8 \pm 6.6$ \\
\hline $\mathbf{3}$ & Saw mill & 74.9 & 77.6 & 84 & $90.9 \pm 2.1$ \\
\hline $\mathbf{4}$ & Furniture factory & 89.7 & 91.9 & 91 & $90.1 \pm 6.4$ \\
\hline $\mathbf{5}$ & Saw mill & 88.7 & 90 & 91.7 & $90.4 \pm 5.2$ \\
\hline $\mathbf{6}$ & Saw mill & 91.3 & 90.3 & 89.5 & $90.7 \pm 4.3$ \\
\hline $\mathbf{7}$ & Furniture factory & 87.1 & 93.5 & 91.5 & $92.1 \pm 5.5$ \\
\hline $\mathbf{8}$ & Saw mill & 91.7 & 90.3 & 94.1 & $89.3 \pm 5.3$ \\
\hline $\mathbf{9}$ & Saw mill & 92.6 & 88.3 & 87.2 & $82.5 \pm 6.9$ \\
\hline $\mathbf{1 0}$ & Furniture factory & 74.9 & 88.5 & 84.1 & \\
\hline
\end{tabular}

Table (5): Multiple linear regression analyses between hearing threshold level $(\mathrm{HTL})$ at each frequency with age, duration in occupation, smoking status and occupation.

\begin{tabular}{|c|c|c|c|c|c|c|}
\hline $\begin{array}{l}\text { Frequency } \\
\qquad(\mathrm{Hz})\end{array}$ & Significant variables & $\begin{array}{l}\text { Regression } \\
\text { coefficient (B) } \\
\text { (dBHL) }\end{array}$ & $95 \% \mathrm{Cl}$ & $\begin{array}{l}\text { Standard } \\
\text { error }\end{array}$ & R2 & P value* \\
\hline 1000 & $\begin{array}{l}\text { Constant } \\
\text { Duration in occupation }\end{array}$ & $\begin{array}{l}3.287 \\
0.009\end{array}$ & $\begin{array}{l}3.241-3.309 \\
0.002-0.013\end{array}$ & $\begin{array}{l}0.033 \\
0.003\end{array}$ & 0.066 & $\begin{array}{r}<0.001 \\
0.004\end{array}$ \\
\hline 2000 & $\begin{array}{l}\text { Constant } \\
\text { Time in occupation }\end{array}$ & $\begin{array}{l}3.087 \\
0.012\end{array}$ & $\begin{array}{l}2.904-3.254 \\
0.008-0.033\end{array}$ & $\begin{array}{l}0.087 \\
0.005 \\
\end{array}$ & 0.072 & $\begin{array}{r}>0.001 \\
0.003 \\
\end{array}$ \\
\hline 3000 & $\begin{array}{l}\text { Constant } \\
\text { Duration in occupation }\end{array}$ & $\begin{array}{l}3.062 \\
0.018\end{array}$ & $\begin{array}{l}2.902-3.248 \\
0.011-0.032\end{array}$ & $\begin{array}{l}0.029 \\
0.005 \\
\end{array}$ & 0.361 & $\begin{array}{l}>0.001 \\
>0.001 \\
\end{array}$ \\
\hline 4000 & $\begin{array}{l}\text { Constant } \\
\text { Duration in occupation } \\
\text { Age }\end{array}$ & $\begin{array}{l}3.014 \\
0.020 \\
0.011\end{array}$ & $\begin{array}{l}2.917-3.215 \\
0.011-0.024 \\
0.003-0.016\end{array}$ & $\begin{array}{l}0.076 \\
0.005 \\
0.004\end{array}$ & 0.346 & $\begin{array}{r}>0.001 \\
>0.001 \\
0.012\end{array}$ \\
\hline 6000 & $\begin{array}{l}\text { Constant } \\
\text { Age }\end{array}$ & $\begin{array}{l}3.007 \\
0.006\end{array}$ & $\begin{array}{l}2.890-3.110 \\
0.002-0.014\end{array}$ & $\begin{array}{l}0.083 \\
0.003\end{array}$ & 0.284 & $\begin{array}{l}>0.001 \\
>0.001\end{array}$ \\
\hline 8000 & $\begin{array}{l}\text { Constant } \\
\text { Age }\end{array}$ & $\begin{array}{l}3.102 \\
0.014\end{array}$ & $\begin{array}{l}2.935-3.283 \\
0.009-0.019\end{array}$ & $\begin{array}{l}0.087 \\
0.004\end{array}$ & 0.176 & $\begin{array}{l}>0.001 \\
>0.001\end{array}$ \\
\hline
\end{tabular}

$\mathrm{dBHL}$ : $\mathrm{dB}$ hearing loss. ${ }^{*} \mathrm{P}<0.050$ indicates statistical significance

\section{DISCUSSION}

Finding of our study showed a high prevalence of noise induced hearing loss (NIHL) in the wood industry in Damietta, Egypt. The data was collected from different ten work places located in New Damietta city with participation of one hundred and fifty (150) wood workers; 105 worked as carpenters and 45 as sawyers. The prevalence of $\mathrm{NIHL}$ was
$39 \%(41 / 105)$ among the carpenters and $44.4 \%$ (20/45) among the sawyers correspondingly. Age of employees $(P=0.001)$ and duration in occupation $(P=0.023)$ were Statistically significant in both groups. In addition, previous exposure to noise among sawyers was $33.3 \%$ which found to be higher than that of carpenters $(14.3 \%)$ with significant difference $(P=0.032)$. Although this 
finding cannot be concluded definitely because of the small sample size of the employees it found to be agreed with a study conducted in Nepal in 2015 which conclude that the prevalence of $\mathrm{NIHL}$ among wood workers was high, $16 \%$ among carpenters, 27 among sawyers \% respectively [6]. The present study was also compatible with a study conducted in Asian countries. This study revealed that the prevalence of noise induced hearing loss in the wood industry was high and the NIHL is one of the most prevalent and preventive occupational issues in these centuries. The main explanations of these findings in our, Asian and Nepal studies could be due to lack of knowledge and awareness about NIHL among employers, employees, and health care workers. It can also be attributed to absence of implementation of hearing conservation programs in the work places [9].

In the present study, LAeq values ranged from 73 to $91.5 \mathrm{dBA}$ and 74.9 to $94.1 \mathrm{dBA}$ at the furniture factories and sawmills respectively. The mean LAeq exceeded the permissible exposure limit (90 dBA) form occupational health and safety administration (OSHA) at five workplaces, three sawmills and tow furniture. Such findings were lower than those reported in a study conducted in Tanzania that established an equivalent average noise level (LAeq) of $102.6 \mathrm{dBA}$ in five small-scale wood industries with a mean peak noise level of 124.4 $\mathrm{dBA}$ [10]. The portable nature of woodwork, intermittent noise type which may not be compatible with the fixed sound level could be considered as a possible explanation why noise readings in the present study differ from those reported in Tanzania study.

However, this study provides evidence that five Damietta wood factories and sawmills operate at or above the permissible exposure limit $90 \mathrm{dBA}$ LAeq, which constitute a significant risk to the hearing of wood workers. These findings were in accordance with a study conducted in Nigeria indicated that $95 \mathrm{~dB}$ was the mean equivalent sound pressure level (LAeq) in the furniture industry[11].

Significant relation was found between the two independent variables age $(P=0.001)$, time in occupation $(P=0.023)$ and hearing threshold level $(\mathrm{HTL})$ of $4 \mathrm{KHz}$ among sawyers and carpenters. This finding was agreed with a study conducted in Ghana to measure effect of hearing loss on work capabilities. It was found in this study a significant correlation between independent variables (threshold noise level, exposure duration) and dependent variable $(\mathrm{NIH})$ in both corm mills and saw mills workers ${ }^{[12]}$.

Previous exposure to noise was significantly higher among sawyers (33\%) than carpenters $(14.3 \%)$ with significant difference $(P=0.032)$ between the both groups. These results came in agreement with the retrospective study conducted in Portuguese which reported that the longer the age and length in occupation as a carpenter, the greater their hearing loss, with significant difference between the NIHL group and normal group to the age $(p=0.001)$, and the duration in the noisy occupation $(p=0,002){ }^{[13]}$.

Conclusions: Occupational $\mathrm{NHH}$ is highly prevalent in Damietta governorate, where noise levels are often not measured and occupational health and safety (OHS) precautions are lacking. The present study concluded that noise induced hearing loss (NIHL) is highly prevalent in the workers working in wood industry in Damietta. In addition, Noise levels were above the standard level of (OSHA) in different furniture factories and saw mills in Damietta governorate. Lack of knowledge and awareness about NIHL among employers, employees, and health care workers in Egypt and absence of hearing conservation programs in the different work places suggested to be one of the main causes of high prevalence of NIHL in wood industry.

\section{Financial and Conflict of interest disclosure}

Authors declare that there was no conflict of interest.

\section{REFERENCES}

1. Nelson DI, Nelson RY, Concha-Barrientos M, Fingerhut $\mathbf{M}$. The global burden of occupational noise-induced hearing loss. Am J Ind Med. 2005; 48(1): 446-58. [DOI: 10.1002/ajim.20223].

2. Rabinowitz PM. Noise-induced hearing loss. Am Fam Physicain 2000;61(9):2759-2760. [PMID: 10821155]. 
3. World Health Organization. WHO Global Estimates on Prevalence of Hearing Loss. 2018. Available online: http:/www.who.int/pbd/deafness/ WHO_GE_HL.pdf (accessed on 14 August 2019).

4. Ryan AF, Kujawa SG, Hammill T, Le Prell C, Kil J. Temporary and permanent noise-induced threshold shifts: a review of basic and clinical observations. Otol Neurotol. 2016;37(8): e271-5. [DOI: 10.1097/MAO.0000000000001071].

5. Suter AH. Occupational Hearing Loss from NonGaussian Noise. Semin Hear. 2017;38(3):225-262. [DOI: 10.1055/s-0037-1603726].

6. Robinson T, Whittaker J, Acharya A, Singh D, Smith M. Prevalence of noise-induced hearing loss among woodworkers in Nepal: a pilot study. Int J Occup Environ Health. 2015;21(1):14-22. [DOI: 10.1179/2049396714Y.0000000084].

7. Hoth S, Baljic I. Current audiological diagnostics. GMS Curr Top Otorhinolaryngol Head Neck Surg. 2017;16: Doc09. [DOI: 10.3205/cto000148].

8. Coles RR, Lutman ME, Buffin JT. Guidelines on the diagnosis of noise-induced hearing loss for medicolegal purposes. Clin Otolaryngol Allied Sci. 2000;25(4):264-73. [DOI: org/10.1046/j.1365-2273. 2000. 00368.x].
9. Fuente A, Hickson L. Noise-induced hearing loss in Asia. Int J Audiol. 2011;50 Suppl 1:S3-10. [DOI: org/10.3109/14992027.2010.540584].

10. Mbuligwe SE. Levels and influencing factors of noise pollution from small-scale industries (SSIs) in a developing country. Environ Manage. 2004; 33(6): 830-9. [DOI: org/10.1007/s00267-003-0060-z].

11. Owoyemi MJ, Falemara BC, Owoyemi AJ. Noise pollution and control in mechanical processing wood industries. Biomed Stat Inf. 2017; 2(2):54-60. [DOI: 10.11648/j.bsi.20170202.13].

12. Boateng CA, Amedofu GK. Industrial noise pollution and its effects on the hearing capabilities of workers: A study from saw mills, printing presses and corn mills. Afr J Health Sci. 2004;11(1-2):55-60. [DOI: org/10.4314/ajhs. v11i1.30778].

13. Farias VH, Buriti AK, Rosa MR. Occurrence of noise induced hearing loss in carpenters. Revista CEFAC. 2012;14(3):413-22. [DOl: org/ 10. 1590/ S1516-18462011005000119]. 